\title{
Implementation and Guarantee of Human Right to Rest in the System of Modern International Relations
}

\author{
Oksana Dordyak \\ $\mathrm{PhD}$ Student at International Law Department, \\ Uzhhorod National University, Ukraine
}

doi: 10.19044/esj.2017.v13n10p70 URL:http://dx.doi.org/10.19044/esj.2017.v13n10p70

\begin{abstract}
This article analyzes the main challenges faced by tourists during the implementation of their right to rest. Various measures taken by states for strengthening national security are arising out of numerous terrorist threats and increasing illegal migration. All these measures are an obstacle to the effective development of tourism. Consumers and producers of travel services are forced to exercise their activity by taking into account many barriers standing in their way. Everyone's right to rest includes the right of freedom of movement, the right to liberty and personal inviolability, the right to a standard of living necessary for the maintenance of health and welfare etc. All these rights are guaranteed by major international legal instruments. Along with these rights, they contain provisions that restrict them. The article examines the main limitation of the above rights and their causes. The author explores scientific review of restrictions on the rights of freedom of movement and migration law of modern states. Violations of Human Rights are analyzed based on the example of cases reviewed by the European Court of Human Rights and the Court of Justice of the European Union. Security and human rights are two key issues that the international community is now trying to combine in regulation without any harm to anyone. The selectivity of modern visa policies provides the basis for the appearance of discrimination. This, however, is not recognized and condemned by international law. Creation of the unified international legal rules based on respect of human rights and security guarantees will facilitate the development of tourism and economy growth of developed and developing countries.
\end{abstract}

Keywords: International law, human rights, migration, tourism, crossborder security 


\section{Introduction}

The development of international norms and institutions for the protection of human rights has reached such a level as never before in the history of mankind. The willingness of people to travel has become an integral part of their lives and the right which is guaranteed by all states. The development of information society has provided an opportunity to receive information about new destinations. Also, it has created new facilitated ways to buy tourism product having made modern tourism accessible for all. Along with this, the global development of transport infrastructure has created a favorable environment for the development of tourism in the most remote corners of the world. Nevertheless, at the same time, terrorism and the war led to the emergence of variety state-regulated activities relating to the security control of documents raised at the borders, visa policy, and new migration laws. Therefore, these measures have raised some obstacles related to the effective implementation of freedom of movement and the right to rest. This is guaranteed by principal international legal instruments on human rights.

Silviu Negut and Marius-Cristian Neacşu (2013, p.46) believe that social prestige of man is no longer determined only on the basis of a career, but also on the amount of free time. In addition, it is confirmed by the fact that the holiday in a modern society, when considered in the complete sense, received the status as one of the basic functions of life. This is along with work, family, housing, communications, culture and so on. This statement in itself shows that tourism refers to the fundamental human rights of freedom of expression and freedom of movement. However, the rules established by international law on human rights and which is related to tourism have a specific feature. They may be restricted in the process of increasing illegal migration that creates different migration policies of states which usually restricts the right to freedom of movement.

Tourism has long become something more than a phenomenon that brings economic benefits. It has been long referred to as the fundamental human rights. Tourism includes the right to travel, and it, in turn, is a part of freedom of movement. The views of scientists differ based on the interpretation of freedom of movement, which is guaranteed by major international legal conventions on human rights.

For example, Matthew Longo (2013) is a supporter of a "broad" definition of the right to travel, which includes related rights such as residence and protection against direct and indirect impediments. Subsequently, this is about the travel which includes not only the movement of a person, but it is also a bundle of rights that make mobility possible. In addition, he believes that such definition satisfies the requirements of a democratic society. 
David Weissbrodt (2015, p.27) considers that: «No general international right to travel between nations exists. The Universal declaration (art 13(1)), the ICCPR (1976) (art 12(1)), the Fourth Protocol to the European Convention on Human Rights (art 2(1)), the American Convention on Human Rights (art. 22(1)), and the African Charter on Human and Peoples' Rights (art 12(1)) do not guarantee travel between nations. Nevertheless, they do provide certain persons the freedom of movement within a state. For example, the ICCPR grants 'the right to liberty of movement' to persons who are "lawfully within the territory within the state". While an individual has the right to leave any nation, the individual does not have the right to enter another nation. Thus, special travel rights are, however, given to stateless persons and to refugees».

The issue of migration control in various countries refers to the socalled barrier to the development of modern mobility and tourism in general. Developed states seek to protect their country from a large influx of migrants from developing countries. Thus, visa policies may vary with respect to each country according to the statistics of the potential influx of migrants from these countries.

A common feature of modern migration policy is its restrictive character. Migration is usually understood in terms of security as a «problem» and many countries feel the need to protect against this «threat». In recent years, terrorism-related apprehension has put the question of borders in the spotlight. In this context, illegal immigration is perceived as a central phenomenon, reflecting the porosity of borders and calls for the increase of surveillance. Also, the management of immigration has become an important area of policy (Pécoud, 2006). Here, it is possible to understand the policy of any state that is trying to protect its citizens in accordance with their constitutions and basic laws as it follows the notion of sovereignty. In addition, security is the basis of the welfare of any country.

\section{Tourism and Migration Policy}

Any person who wishes to travel to another country may generally do this. This is possible only after passing the necessary procedures required by the country of destination. These procedures vary depending on the nationality of the person who intends to travel and the visa policy of the country of destination for such person. Borders have a "polysemic" character. From a practical point of view, this reflects the fact that they do not have one meaning for all. Nothing is regarded as a less tangible thing than borders. Even if it is official, there is "no difference" in what capacity you cross the border - you can go through it as a businessman, a scientist that is going to a conference, or young unemployed. In this case, the border 
acquires a different nature for everyone, which has nothing in common except the name (Balibar, 2002).

For the majority of tourists who wish to travel abroad, the border starts with a necessity of obtaining a visa, which is required for a range of foreigners. Of course, some passports provide privileges and the possibility of free movement, while the passports of other countries can greatly restrict free movement. Almost all countries require the availability of a visa from citizens of a certain category of states that wish to enter their territory. However, visa policy has really become one of the key arrangements for structuring a global mobility. For example, some of the reasons which caused the emergence of different visa requirements for citizens from different countries can be economic, social, and cultural reasons. That is, in creating visa policy for foreigners, the state analyzes the level of economic, social or cultural development of other countries that helps to identify the states from which migrants can potentially come and stay illegally. Among such countries are also those from which foreigners often arrive on a tourist visa, overstay their visa, and remain on the territory illegally (Mau et al., 2012).

Eric Neumayer (2006) considers that visa restrictions perform a dual role of pre-selection and deterrence. So, those who do not need a visa are considered desirable. Those who need a visa and have been approved by the consulate or embassy of the country abroad are not considered undesirable. Also, they do not represent a great risk if their issue will be under closer inspection. On the other hand, those who need a visa and do not have one or have been denied a visa are unwelcome.

Concerning discrimination and selectivity in visa policies, the judgment of the European Court of Human Rights in case Timishev v Russia (2005) should be mentioned here. The paragraph 58 of this judgment states: «no difference in treatment which is based exclusively or to a decisive extent on a person's ethnic origin is capable of being objectively justified in a contemporary democratic society built on the principles of pluralism and respect for different cultures».

Realizing the existence of selectivity in visa policy leads to the question about the existence of discrimination against certain groups of people. Simple persons who just want to visit historical sites, pass a monthly language course, and that visit friends in the country that require a visa for it frequently face the challenge of discrimination. For example, if consulate or embassy will rely on statistics that highlights countries from which potential migrants are arriving, all other citizens of this country who do not aim to get a permanent residence but just wish to go on a tourist trip might be covered by these statistics. 
Consequently, such selectivity in visa policy, despite its discriminatory nature, is nevertheless justified. For example, a procedure that exists in the rules concerning entry of citizens from the third countries to the EU is justified in the decisions of the European Court of Human Rights on the basis of identification of regime of the EU as a «special public order». However, this also indicated that the rules allows people of the third countries to be inspected differently before crossing the EU border (Cholewinski, 2002). Regarding the number and nature of the supporting documents that applicants must possess, they can vary significantly depending on the country in which the application is submitted. The number and type of required supporting documents vary depending on the possible risk of illegal immigration and the local situation (for example, whether the currency is convertible) and may vary in different countries (Cholewinski, 2002).

As a rule, a procedure of examination of documents when applying for a visa includes rules that are created within the country and that are in accordance with its immigration policy. This, of course, facilitates individuals who are responsible for issuing visas to inspect according to the rules and in permitted limits to avoid direct discrimination. An example of the establishment of these rules may be adopted within the Schengen zone Visa Code of the European Union (Visa Code), which establishes the procedure and conditions for issuing visas (Regulation (EC) No 810/2009). Article 14 of the Visa Code provides a list of required documents for a visa. Among these documents are documents indicating the purpose of the trip; documents in relation to accommodation, or proof of sufficient means to cover his accommodation; documents showing that the applicant possesses sufficient means of subsistence both for the duration of the intended stay and for the return to his country of origin or residence, or for the transit to a third country; information enabling an assessment of the applicant's intention to leave the territory of the Member States before the expiry of the visa he/she applied for (Regulation (EC) No 810/2009).

Also, Visa Code provides a clear list of reasons for which visa may be refused. Other reasons are not allowed, and it was confirmed in the judgment of European Court of Justice on Rahmanian Koushkaki $v$ Bundesrepublik Deutschland case. However, the circumstances of the case concerned the refusal of a visa to Mr. Rahmanian by German Embassy in Tehran due to lack of sufficient funds to return to the country of residence. He appealed to the decision and filed a second application and it was refused again. Nevertheless, this was with a new rationale which included serious doubts of the embassy for his return back to the expiration of visa. In 2011, Mr. Rahmanian appealed to the relevant court in Germany with a complaint which the court suspended and handed over based on the decision of the 
Court of Justice of the European Union. They explained that, overall, he meets all the conditions of the Visa Code for the issue of a visa, but there are doubts and risks of illegal migration. German court raised the question of possibility for refusing a visa on the basis of doubts. Court of Justice of the European Union decided that the authorities of the Member States cannot refuse to issue a "Schengen visa" to the applicant if there is not one of the grounds for refusal listed in the Visa Code. Also, national authorities have much leeway in terms of establishing this fact. Visa should be refused if there is reasonable doubt about the intention of the applicant to leave the territory of the Member States before the expiry of the requested visa. To determine the presence of reasonable doubt about this intent, the competent authorities should individually consider an application for a visa. This should be done by taking into account the general situation in the country of residence of the applicant and the personal characteristics of the applicant, including his family, social and economic situation, and the fact whether he resided legally or illegally in one of the Member states, and also his ties to the country of residence and the Member states (Rahmanian Koushkaki $v$ Bundesrepublik Deutschland, 2013).

It is important to emphasize that within the existing Visa Code, Article 39 provides an appeal for the refusal of a visa (Regulation (EC) No 810/2009, Art 39). Such an appeal can be submitted to a Member State, which adopted a final decision under the national law of that State. This is a proof that in any case, in the event of unfair rejection, anyone can make appeal on their violated rights. In the face of a democratic society, human rights are guaranteed at the level of fundamental international documents and it is very important when an appeal can be made to their violation. However, this means that despite the closed migration policies, each person still has the right to appeal against an unfair and preconceived attitude that usually occurs towards the citizens of the countries of potential migration who just want to visit a particular country. The decision of the Court of the European Union emphasized that each case is unique. Therefore, in order to avoid discrimination, personal inspection of each applicant should be conducted.

Unfortunately, a visa for a trip is not the only obstacle. To have a visa, a tourist must further cross the border with a State to which he travels. Crossing the border can be called the most obvious limitation of mobility. International journey necessarily includes border crossing. Control on the border reflects the central tension faced by a modern nation that combines the desire to protect and the desire to facilitate mobility. Hence, this desire is necessary for trade, tourism, diplomacy, human rights guarantees and the exchange of information, but could potentially threaten internal security (Lovelock \& Lovelock, 2013). 
Antoine Pécoud and Paul de Guchteneire (2006, p.73) believe that the concept of "security" is ambiguous. Although a comprehensive understanding of security should encompass both national and human security and therefore incorporate human rights, dominant approaches focus overwhelmingly on national security to the detriment of the well-being of people, particularly non-nationals.

However, the control faced by tourists at the border is justified by international law. When considering the scope of the right to freedom of movement, it is worth noting that its restriction is legalized in the main international legal instruments. For example, in the European Convention on Human Rights (1950), namely the Protocol 4, Article 2 (3) states that freedom of movement may be restricted in cases: « as are in accordance with law and are necessary in a democratic society in the interests of national security or public safety, for the maintenance of ordre public, for the prevention of crime, for the protection of health or morals, or for the protection of the rights and freedoms of others».

International Covenant on Civil and Political Rights (1976) in Article 12 (3) provides that the rights to freedom of movement, predicted by Covenant: "shall not be subject to any restrictions except those which are provided by law, are necessary to protect national security, public order (ordre public), public health or morals or the rights and freedoms of others, and are consistent with the other rights recognized in the present Covenant».

Certainly, measures taken at the borders to protect public safety were also important for tourism. When choosing a destination for tourist trips, anyone will pay attention to security issues of stay in a country. Today, it is very important by taking into the account the current terrorist threat that has been developed in the world. Terrorist attacks are always scaring tourists. Accordingly, the flow of tourists are reducing in the injured country. Thus, the most resonance event that has influenced the change of border controls is a terrorist attack in the United States on the 11th of September 2001. Following these events, the international community has changed its legislation to strengthen national security. Also, border control has become a major issue of international cooperation that facilitated the creation of appropriate alliances.

Appropriate control can be felt by every tourist. Certainly, nobody will protest against it because it as to do with the safety of both the citizens of a State and the foreigners who came for a visit. However, at the same time arises a problem regarding reasonable time and frames in which such control can be provided. The question is also about the violation of the right to liberty and security of person. This includes both check-in for the international flight and the intersection of the border by vehicle. 
Subsequently, the answer to this question can be found in ECHR judgment in Gahramanov v. Azerbaijan case. This was regarding the unlawful detention of Mr. Gahramanov for inspection at the airport for several hours which was held under administrative error. In this case, the Court stated : «given the multitude of situations in modern society where the public may be called on to endure restrictions on freedom of movement or liberty in the interests of the common good, an air traveller must be seen as consenting to a series of security checks by choosing to travel by plane. Those measures might include identity checks, baggage searches or waiting for further inquiries to be made in order to establish whether he or she represents a security risk for the flight. Accordingly, where a passenger was stopped during airport border control in order to clarify his situation for no more than the time strictly necessary to accomplish the relevant formalities...» (Information Note on the Court's case-law No. 168 Gahramanov v. Azerbaijan, 2013) . The Court decided that the overall duration of applicant's stay in a separate room could not exceed a few hours and the applicant's inspections in the room exceeded the time strictly necessary to search his luggage and in fulfilling the relevant administrative formalities for the clarification of his situation. Accordingly, after it was determined that the warning in the database was as a result of an administrative error, the applicant must freely leave the airport. Therefore, his detention cannot be justified within the meaning of Article 5 of the European Convention on Human Rights (Information Note on the Court's case-law No. 168 Gahramanov v. Azerbaijan, 2013).

Furthermore, such a decision can effectively influence the future regulation and establishing procedures that are necessary for border security purposes. Limitations of human rights should be provided in "smart" frameworks. In addition, any abuse in this area can lead to gross violations of human rights.

\section{Conclusion}

In conclusion, it is important to understand that tourism development will always depend on regulations that may inhibit it. Concerning the main obstacles faced by people using their right to rest and freedom of movement, it has to do with those same limitations on these rights. The international community should emphasize the human right to travel to another country in the formation of policy concerning the regulation of illegal migration. The more checks and formalities at the border, the more this hinders tourism. Traveling abroad may certainly have different objectives - to relax or to search for work or permanent residence. In the process of the identification of potential and actual migrant, every new tourist can be perceived as potential migrants. Of course, this does not concern persons who have a good 
visa history. Today, migration and tourism are two concepts that partially cover one another. However, this is probably due to the fact that tourism could turn into migration. This is a problem usually faced by consulates and embassies during the issue of a visa. The reason is in conjectures and trust to a person concerning his return to his country of residence to the expiry of his tourist visa. Today, security and human rights are two key issues that the international community is trying to combine in the regulation without causing any harm to anyone. The basic international legal restrictions on human rights, which can take place in accordance with the purposes of national security, are a matter of sovereignty. This is alongside with various limitations and existing international courts and standards that guarantee the right to a fair trial. These right provides an opportunity to create reasonable frameworks for such limitations. Also, the number of lawsuits related to the restriction of rights for the purposes of national security increases. However, decisions of international courts with respect to such cases efficiently help to cooperate with the further effective regulation of security issues. These issues are issues that are affecting human rights and it can also help citizens to protect their violated rights.

\section{References:}

1. Balibar, E. (2002). Politics and the Other Scene. London/New York:Verso.

2. Cholewinski, R. (2002). Borders And Discrimination in the European Union. London/Brussels: Immigration Law Practitioners' Association/Migration Policy Group.

3. ICCPR (1976). United Nations General Assembly International Covenant on Civil and Political Rights, Mar. 23.

4. Information Note on the Court's case-law No. 168 Gahramanov v. Azerbaijan ( App. no 26291/06), ECHR I 2013, Retrieved from: http://hudoc.echr.coe.int/eng? $\mathrm{i}=002-9121$

5. Judgement of the Court (Grand Chamber) of 19 December 2013, Rahmanian Koushkaki v Bundesrepublik Deutschland, Case C-84/12, ECLI:EU:C:2013:862

6. Longo, M. (2013). Right of way? Defining Freedom of Movement within Democratic Societies. In W. Maas (Ed.), Democratic Citizenship and the Free Movement of People.(Vol.30). Leiden:Martinus Nijhoff Publishers.

7. Lovelock B. \& Lovelock K. (2013). The Ethics of Tourism: Critical and Applied Perspectives. London/New York: Routledge.

8. Mau S., Brabandt H., Laube L., \& Roos C. (2012). Liberal States and the Freedom of Movement: Selective Borders, Unequal Mobility. Chippenham: Palgrave Macmillan. 
9. Negut, S. \& Neacşu, M.C. (2013). Tourism, expression of freedom in the global era. International Journal for Responsible Tourism, 45-53.

10. Neumayer, E. (2006). Unequal access to foreign spaces : how states use visa restrictions to regulate mobility in a globalized world [online]. London: LSE Research Online. Retrieved from: http://eprints.lse.ac.uk/archive/00000715

11. Pécoud, A. (2006). International Migration, Border Controls and Human Rights: Assessing the Relevance of a Right to Mobility . Journal of Borderlands Studies, 21(1), 69-86. Retrieved from : http://lastradainternational.org/lsidocs/626\%20intl_migration_brder _cntrl_070402.pdf

12. Regulation (EC) No 810/2009 of the European Parliament and of the Council of 13 July 2009 establishing a Community Code on Visas (Visa Code)

13. Timishev v. Russia (App. no 55762/00 and 55974/00), ECHR 2005II, at para 58.

14. Weissbrodt, D. (2015). Human Rights of Noncitizens. In HowardHassmann, Rhoda E.., \& Walton-Roberts, M. (Ed.), The Human Right to Citizenship: A Slippery Concept. Philadelphia: University of Pennsylvania Press. 